\title{
Prolonged rectal shedding of SARS-CoV-2 in a 22-day-old-neonate: a case report
}

\author{
Julie Niemann Holm-Jacobsen ${ }^{1}$, Julia Helena Vonasek², Søren Hagstrøm³ ${ }^{3,4}$, Mette Line Donneborg ${ }^{1,2,4}$ and
}

Suzette Sørensen ${ }^{1, *^{*}}$ (1)

\begin{abstract}
Background: Severe acute respiratory syndrome coronavirus 2 (SARS-CoV-2) causes the novel coronavirus disease 2019 (COVID-19), which is characterized by a diverse clinical picture. Children are often asymptomatic or experience mild symptoms and have a milder disease course compared to adults. Rectal shedding of SARS-CoV-2 has been observed in both adults and children, suggesting the fecal-oral route as a potential route of transmission. However, only a few studies have investigated this in neonates. We present a neonate with a mild disease course and prolonged rectal SARS-CoV-2 shedding.

Case presentation: A 22-day old neonate was admitted to the hospital with tachycardia and a family history of COVID-19. The boy later tested positive for COVID-19. His heart rate normalized overnight without intervention, but a grade $1 / 6$ heart murmur on the left side of the sternum was found. After excluding signs of heart failure, the boy was discharged in a habitual state after three days of admission. During his admission, he was enrolled in a clinical study examining the rectal shedding of SARS-CoV-2. He was positive for SARS-CoV-2 in his pharyngeal swabs for 11 days after initial diagnosis and remained positive in his rectal swabs for 45 days. Thereby, the boy remained positive in his rectal swabs for 29 days after his first negative pharyngeal swab.
\end{abstract}

Conclusions: The presented case shows that neonates with a mild disease course can shed SARS-CoV-2 in the intestines for 45 days. In the current case, it was not possible to determine if fecal-oral transfer to the family occurred, and more research is needed to establish the potential risk of the fecal-oral transmission route.

Keywords: COVID-19, SARS-CoV-2, Neonate, Rectal shedding, Case report

\section{Background}

Severe acute respiratory syndrome coronavirus 2 (SARS-CoV-2) has resulted in a worldwide pandemic since its outbreak in Wuhan, China, in December 2019 $[1,2]$. To date, the virus has globally infected more than 230 million people and has led to nearly five million deaths [3]. Infection with SARS-CoV-2 causes the novel coronavirus disease 2019 (COVID-19), which is characterized by a diverse clinical picture. The disease

\footnotetext{
${ }^{*}$ Correspondence: suzette.soerensen@rn.dk

${ }^{1}$ Centre for Clinical Research, North Denmark Regional Hospital,

Bispensgade 37, 9800 Hjoerring, Denmark

Full list of author information is available at the end of the article
}

can present with clinical manifestations such as fever, cough, and dyspnea but can also be asymptomatic [49]. In critical cases, infection with SARS-CoV-2 may result in respiratory failure, septic shock, multi-organ failure, and/or death [10, 11].

Children most often have a milder disease course compared to adults $[9,10]$. They are often asymptomatic or experience mild symptoms, such as fever and cough [9, 12-15], and critical cases are less common [9]. However, a few children, including neonates, develop multisystem inflammatory syndrome (MIS-C) after COVID-19 [16-19].

The primary transmission routes of SARS-CoV-2 are through close contact with infected people and inhalation 
of respiratory droplets and aerosol particles [20-27]. However, other transmission routes have been suggested, including the fecal-oral route [28-31]. Studies have shown that both adults [28, 32, 33] and children [12, 13, 33-35] can shed SARS-CoV-2 in the stool. It has been estimated that rectal SARS-CoV-2 shedding can be detected, in either stool samples or rectal swabs, in $43 \%$ of COVID-19 patients [36]. Notably, a large fraction of the patients continues to display rectal SARS-CoV-2 shedding, even after the virus has been cleared from the respiratory tract [36]. For children particularly, the prevalence of rectal SARSCoV-2 shedding is even higher; ranging from 52.6-91.8 \% [37-40]. Children have been reported to exert prolonged shedding of SARS-CoV-2 in the intestines for 2-70 days after initial testing with a mean value of $30.8 \pm 18.6$ days for symptomatic children and $28.1 \pm 13.3$ days for asymptomatic children [40]. Furthermore, most children continue to be positive in the stool after respiratory samples have become negative [38-40]. Only a few studies have investigated rectal SARS-CoV-2 shedding in neonates [34, 41-43]. Of these, two studies followed the neonates until they became negative in the rectal swabs or stool, which lasted for four and 42 days, respectively $[34,43]$.

The present case report describes the shedding of SARS-CoV-2 in the pharynx and the rectum of a 22-dayold neonate, to draw further attention to the possible prolonged shedding of SARS-CoV-2 in neonates.

\section{Case presentation}

We present a case of a 22-day old boy who was admitted to the pediatric ward at the North Denmark Regional Hospital in Hjoerring, Denmark, with an active COVID-19 infection.

The boy was born at term, after an uncomplicated pregnancy, with a birth weight of $3470 \mathrm{~g}$, and a normal APGAR score together with an otherwise normal perinatal period. The boy was bottle-fed and well-being with a normal weight gain.

At 21 days of age, the family contacted the pediatric ward because the boy's father and oldest sister were tested positive for COVID-19, and the boy had been irritable for 2 hours and had a temperature of $38.3{ }^{\circ} \mathrm{C}$. A few hours later, the temperature had dropped to 37.8 ${ }^{\circ} \mathrm{C}$, and the boy was no longer irritable. Both the father and sister were asymptomatic.

At admission, the boy presented no respiratory difficulties, however, he had tachycardia of 200 beats/minute and was pale. He had a body temperature of $37.3^{\circ} \mathrm{C}$, respiratory rate of 48 breaths/minute, small intercostal retractions, normal stethoscopy of the lungs and heart, and an otherwise normal neonatal examination and vital values. The child underwent a COVID-19 pharyngeal PCR-test, a chest and abdomen $\mathrm{x}$-ray as well as screening blood analyses, and an electrocardiogram (ECG) (Table 1).

Table 1 Laboratory findings

\begin{tabular}{|c|c|c|c|c|}
\hline & Reference interval & Day 1 & Day 2 & Day 3 \\
\hline ECG & $\begin{array}{l}\text { Sinus rhythm, 100-160 beats/ } \\
\text { minute }\end{array}$ & $\begin{array}{l}\text { At admission: } \\
\text { Sinus rhythm, } 190 \text { beats/minute } \\
12 \text { hours after admission: } \\
\text { Sinus rhythm, } 169 \text { beats/minute }\end{array}$ & & $\begin{array}{l}\text { Sinus rhythm, } \\
159 \text { beats/ } \\
\text { minute }\end{array}$ \\
\hline CRP & $<8.0 \mathrm{mg} / \mathrm{L}$ & $<4$ & & $<4$ \\
\hline Haemoglobin & $6.8-12.5 \mathrm{mmol} / \mathrm{L}$ & 9.6 & & \\
\hline Thrombocytes & $120-55510^{9} / \mathrm{L}$ & 224 & & 262 \\
\hline Leucocytes & $6.9-19.910^{9} / \mathrm{L}$ & 10.2 & & 15.3 \\
\hline Creatinine & $17-41 \mu \mathrm{mol} / \mathrm{L}$ & 21 & & \\
\hline Alanine transaminase & $1-40 \mathrm{U} / \mathrm{L}$ & 57 & & \\
\hline $\mathrm{pH}^{\mathrm{a}}$ & $7.37-7.45$ & 7.38 & & \\
\hline $\mathrm{pCO}_{2}{ }^{\mathrm{a}}$ & $3.8-6.5 \mathrm{kPa}$ & 5.7 & & \\
\hline Bicarbonate $^{a}$ & $21.3-26.5 \mathrm{mmol} / \mathrm{L}$ & 24.3 & & \\
\hline Lactate $^{a}$ & $0.5-1.6 \mathrm{mmol} / \mathrm{L}$ & 2.1 & & \\
\hline ProBNP & $<300$ ng/L & 708 & 785 & \\
\hline Creatinine kinase & $30-470 \mathrm{U} / \mathrm{L}$ & 139 & 168 & 125 \\
\hline Creatinine Kinase MB & $<7.0 \mu \mathrm{g} / \mathrm{L}$ & 7.0 & 8.2 & 6.6 \\
\hline Troponin I & $\begin{array}{l}\text { No reference values } \\
\mathrm{ng} / \mathrm{L}\end{array}$ & 48 & 49 & \\
\hline
\end{tabular}

Numbers in bold indicate values that are outside the reference interval

${ }^{\text {a }}$ Capillary samples 
The x-ray and ECG were normal. For laboratory findings, see Table 1 . Overnight, his heart rate normalized without intervention, and along with this a normalization of skin color was seen. In the morning, the COVID19 test came back positive. A grade 1/6 heart murmur on the left side of the sternum was found, and a pediatric cardiologist was consulted. It was decided to repeat the ECG and take blood samples for heart enzymes to rule out MIS-C (Table 1). The pediatric cardiologist concluded that there were no signs of heart failure biochemically or clinically. After the first hours, the heart rate was stable at $130-160$ beats/minute, although slightly higher when he showed signs of irritability, and he was normothermic. The boy was discharged in a habitual state after three days of admission. A follow-up echocardiography one month after admission was normal. Two days after the boy was discharged, the mother tested positive for COVID-19. To our knowledge, the second sister remained negative.

Due to the positive COVID-19 test, the boy was enrolled in a clinical study (N-20200036) at the North Denmark Regional Hospital, examining rectal shedding of SARS-CoV-2. During hospitalization, an extra pharyngeal and two rectal swabs were collected. Prior to discharge, the mother was thoroughly instructed in how to perform pharyngeal and rectal swabs, and was asked to continue sample collection at home, until two consecutive negative pharyngeal and rectal swabs were obtained. Figure 1 shows the number and frequency of samples taken.

Pharyngeal swabs were positive for 11 days after initial diagnosis, and the collection of pharyngeal swabs was stopped after two consecutive negative results on day 25 . After this, the mother was instructed to continue with the rectal swabs only. The boy was SARS-CoV-2 positive in his rectal swabs for 45 days, and the sample collection ended on day 53 with two consecutive negative results. Thus, the boy remained positive in his rectal swabs for 29 days after his first negative pharyngeal swab.

At inclusion, the mother completed a questionnaire regarding the boy's demographic and medical information, including height, weight, symptoms, contact with SARS-CoV-2 infected individuals, risk factors, etc. In addition, the mother completed a questionnaire about the boy's symptoms at each sample collection time point. After discharge, the boy remained asymptomatic during the whole pharyngeal and/or rectal swab follow-up period. The boy had an average weight gain of $37.6 \mathrm{~g} /$ day during the first month after the positive COVID-19 test, hence, the prolonged shedding of virus did not affect the boy's well-being.

\section{Discussion and Conclusions}

We have presented a case of a 22-day-old COVID-19 neonate with prolonged rectal SARS-CoV-2 shedding. He experienced a mild fever before hospitalization but remained asymptomatic during his involvement in this study. His mild disease course is in line with current reports on clinical manifestations among neonates with COVID-19 [41, 43-46]. The degree and duration of rectal SARS-CoV-2 shedding in neonates is, however, not very well described, and only a few studies have addressed this [34, 41-43]. These studies described neonates with prolonged rectal shedding after initial testing, and most of the neonates had a mild disease course. One of the studies described a neonate with mild symptoms and rectal shedding for 42 days [34]. Therefore, it appears that SARS-CoV-2 resides in the intestines of some neonates, for a relatively long period, without necessarily contributing to the symptoms or severity of the COVID-19 disease. It could be speculated that the combination of mild COVID-19 disease phenotype along with the observed prolongated presence of SARS-CoV-2 in the intestine mirror the unique immune compartment of infancy [47]. However, it is not known if long-term consequences such as influence on gut microbiota establishment could arise or if normal gut function or immune responses could be affected later in life.

The finding of SARS-CoV-2 in stool of neonates could potentially constitute a risk of transferring the virus to close contacts, such as the parents, siblings, or caretakers. Solid evidence for a fecal-oral transmission route for SARS-CoV-2 has not been established, but a few studies have been able to isolate replication-competent virus from stool or rectal swabs [29-31]. In addition, the angiotensin converting enzyme 2 receptor, known to be required for cellular entry of SARS-CoV-2, has been detected on intestinal cells $[48,49]$. This, together

Pharyngeal swab Pharyngeal swab
Rectal swab

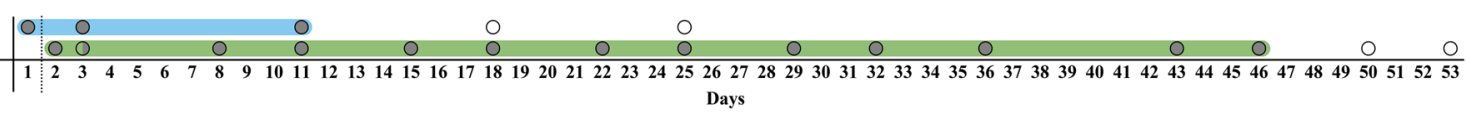

Fig. 1 Timeline of results from pharyngeal and rectal swabs analyzed by PCR-based test. Day 1 is the time of COVID-19 diagnosis, and day 2 is the day of inclusion in the clinical study. Grey circleso demonstrate a positive result, transparent circleso demonstrate a negative result, and half-filled circleso demonstrate an inconclusive result. The blue box marks the period of positive pharyngeal swabs, while the green box marks the period of positive rectal swabs 
with the prolonged presence of rectal shedding, supports the likelihood that the virus actively exerts its life cycle in the intestines of COVID-19 patients instead of being non-infectious leftovers. In the current case, it was not possible to determine if any fecal-oral transfer from the neonate to family members occurred since the mother could have been infected during other circumstances.

More research is needed to establish whether prolonged presence of SARS-CoV-2 in neonates could exert a health risk for the child, but also if extra precautionary measures should be taken to prevent viral transmission from stool. The latter, in particular, when considering that a high fraction of COVID-19 positive infants/children present with rectal SARS-CoV-2 shedding and are simultaneously asymptomatic.

\section{Abbreviations}

COVID-19: Coronavirus disease 2019; ECG: Electrocardiogram; MIS-C: Multisystem inflammatory syndrome in children; SARS-CoV-2: Severe acute respiratory syndrome coronavirus 2.

\section{Acknowledgements}

We thank Ann-Maria Jensen, Bente Marckstrøm Jensen, and Anne Sofie Vedsted, Centre for Clinical Research, North Denmark Regional Hospital, for their work in the laboratory. Furthermore, we thank the patient's family for granting permission to publish this information.

\section{Authors' contributions}

Data extraction was performed by JH and JV. JH and JV drafted the initial manuscript, while SH, MR, and SS contributed to editing and finalizing the manuscript. All authors read and approved the final manuscript.

\section{Funding}

This study was funded by the Novo Nordisk Foundation; grand number NNF20SA0062182. The funding source was not involved in study design, sample collection, analysis, interpretation of data, or preparation of the manuscript.

\section{Availability of data and materials}

The datasets used and/or analyzed during the current study are available from the corresponding author on reasonable request.

\section{Declarations}

\section{Ethics approval and consent to participate}

The study was approved by the North Denmark Region Committee on Health Research Ethics (N-20200036). Informed consent was obtained from the parents of the child.

\section{Consent for publication}

Written informed consent was obtained from the parents of the child for publication of this case report. A copy of the written consent is available for review by the Editor of this journal.

\section{Competing interests}

The authors declare that they have no competing interests.

\section{Author details}

${ }^{1}$ Centre for Clinical Research, North Denmark Regional Hospital, Bispensgade 37, 9800 Hjoerring, Denmark. ${ }^{2}$ Department of Pediatrics, North Denmark Regional Hospital, Hjoerring, Denmark. ${ }^{3}$ Department of Pediatrics, Aalborg
University Hospital, Aalborg, Denmark. ${ }^{4}$ Department of Clinical Medicine, Aalborg University, Aalborg, Denmark.

Received: 1 July 2021 Accepted: 26 October 2021

Published online: 12 November 2021

\section{References}

1. World Health Organization. WHO announces COVID-19 outbreak a pandemic: World Health Organization; 2020. https://www.euro.who.int/ en/health-topics/health-emergencies/coronavirus-covid-19/news/news/ 2020/3/who-announces-covid-19-outbreak-a-pandemic. Accessed 30 June 2021

2. World Health Organization. Novel coronavirus (2019-nCoV) SITUATION REPORT - 1: World Health Organization; 2020. p. 5. https://apps.who.int/ iris/handle/10665/330760. Accessed 30 Jun 2021

3. World Health Organization. WHO Coronavirus (COVID-19) dashboard: World Health Organization; 2021. https://covid19.who.int/. Accessed 6 Oct 2021

4. Guan W, Ni Z, Hu Y, Liang W, Ou C, He J, et al. Clinical characteristics of coronavirus disease 2019 in China. N Engl J Med. 2020;382:1708-20. https://doi.org/10.1056/NEJMoa2002032.

5. Huang C, Wang Y, Li X, Ren L, Zhao J, Hu Y, et al. Clinical features of patients infected with 2019 novel coronavirus in Wuhan, China. Lancet. 2020;395:497-506. https://doi.org/10.1016/S0140-6736(20)30183-5.

6. Goyal P, Choi JJ, Pinheiro LC, Schenck EJ, Chen R, Jabri A, et al. Clinical characteristics of covid-19 in New York City. N Engl J Med. 2020;382:23724. https://doi.org/10.1056/NEJMc2010419.

7. Lavezzo E, Franchin E, Ciavarella C, Cuomo-Dannenburg G, Barzon L, Del Vecchio C, et al. Suppression of a SARS-CoV-2 outbreak in the Italian municipality of Vo'. Nature. 2020;584:425-9. https://doi.org/10.1038/ s41586-020-2488-1.

8. Mizumoto K, Kagaya K, Zarebski A, Chowell G. Estimating the asymptomatic proportion of coronavirus disease 2019 (COVID-19) cases on board the Diamond Princess cruise ship, Yokohama, Japan, 2020. Eurosurveillance. 2020;25:2000180. https://doi.org/10.2807/1560-7917.ES.2020.25.10. 2000180.

9. Dong Y, Mo X, Hu Y, Qi X, Jiang F, Jiang Z, et al. Epidemiology of COVID-19 among children in China. Pediatrics. 2020;145:e20200702. https://doi.org/ 10.1542/peds.2020-0702.

10. China CDC Weekly. The epidemiological characteristics of an outbreak of 2019 novel coronavirus diseases (COVID-19) - China, 2020. China CDC Wkly. 2020;2:113-22. https://doi.org/10.46234/ccdcw2020.032.

11. Yang X, Yu Y, Xu J, Shu H, Xia J, Liu H, et al. Clinical course and outcomes of critically ill patients with SARS-CoV-2 pneumonia in Wuhan, China: a single-centered, retrospective, observational study. Lancet Respir Med. 2020;8:475-81. https://doi.org/10.1016/S2213-2600(20)30079-5.

12. Jiehao $C$, Jin $X$, Daojiong L, Zhi Y, Lei X, Zhenghai $Q$, et al. A case series of children with 2019 novel coronavirus infection: clinical and epidemiological features. Clin Infect Dis. 2020;71:1547-51. https://doi.org/10.1093/cid/ ciaa198.

13. Xu Y, Li X, Zhu B, Liang H, Fang C, Gong Y, et al. Characteristics of pediatric SARS-CoV-2 infection and potential evidence for persistent fecal viral shedding. Nat Med. 2020;26:502-5. https://doi.org/10.1038/ s41591-020-0817-4.

14. Lu X, Zhang L, Du H, Zhang J, Li YY, Qu J, et al. SARS-CoV-2 infection in children. N Engl J Med. 2020;382:1663-5. https://doi.org/10.1056/NEJMc 2005073.

15. Xia W, Shao J, Guo Y, Peng X, Li Z, Hu D. Clinical and CT features in pediatric patients with COVID-19 infection: different points from adults. Pediatr Pulmonol. 2020;55:1169-74. https://doi.org/10.1002/ppul.24718.

16. Dufort EM, Koumans EH, Chow EJ, Rosenthal EM, Muse A, Rowlands J, et al. Multisystem inflammatory syndrome in children in New York State. N Engl J Med. 2020;383:347-58. https://doi.org/10.1056/NEJMoa2021756.

17. Feldstein LR, Rose EB, Horwitz SM, Collins JP, Newhams MM, Son MBF, et al. Multisystem inflammatory syndrome in U.S. Children and adolescents. N Engl J Med. 2020;383:334-46. https://doi.org/10.1056/NEJMo a2021680. 
18. Kappanayil M, Balan S, Alawani S, Mohanty S, Leeladharan SP, Gangadharan $S$, et al. Multisystem inflammatory syndrome in a neonate, temporally associated with prenatal exposure to SARS-CoV-2: a case report. Lancet Child Adolesc Heal. 2021;5:304-8. https://doi.org/10.1016/ S2352-4642(21)00055-9.

19. Shaiba LA, Hadid A, Altirkawi KA, Bakheet HM, Alherz AM, Hussain SA, et al. Case report: neonatal multi-system inflammatory syndrome associated with SARS-CoV-2 exposure in two cases from Saudi Arabia. Front Pediatr. 2021;9:1-8. https://doi.org/10.3389/fped.2021.652857.

20. Li Q, Guan X, Wu P, Wang X, Zhou L, Tong Y, et al. Early transmission dynamics in Wuhan, China, of novel coronavirus-infected pneumonia. N Engl J Med. 2020;382:1199-207. https://doi.org/10.1056/NEJMoa2001316.

21. Chan JF-W, Yuan S, Kok K-H, To KK-W, Chu H, Yang J, et al. A familial cluster of pneumonia associated with the 2019 novel coronavirus indicating person-to-person transmission: a study of a family cluster. Lancet. 2020;395:514-23. https://doi.org/10.1016/S0140-6736(20)30154-9.

22. Hamner L, Dubbel P, Capron I, Ross A, Jordan A, Lee J, et al. High SARSCoV-2 attack rate following exposure at a choir practice - Skagit County, Washington, March 2020. MMWR Morb Mortal Wkly Rep. 2020;69:606-10. https://doi.org/10.15585/mmwr.mm6919e6.

23. Ghinai I, McPherson TD, Hunter JC, Kirking HL, Christiansen D, Joshi $\mathrm{K}$, et al. First known person-to-person transmission of severe acute respiratory syndrome coronavirus 2 (SARS-CoV-2) in the USA. Lancet. 2020;395:1137-44. https://doi.org/10.1016/S0140-6736(20)30607-3.

24. Lu J, Gu J, Li K, Xu C, Su W, Lai Z, et al. COVID-19 outbreak associated with air conditioning in restaurant, Guangzhou, China, 2020. Emerg Infect Dis. 2020;26:1628-31. https://doi.org/10.3201/eid2607.200764.

25. World Health Organization. Coronavirus disease (COVID-19): How is it transmitted? World Health Organization; 2020. https://www.who.int/ news-room/q-a-detail/coronavirus-disease-covid-19-how-is-it-transmitted. Accessed 30 June 2021

26. Centers for Disease Control and Prevention (CDC). Scientific Brief: SARSCoV-2 Transmission: Centers for Disease Control and Prevention (CDC); 2021. https://www.cdc.gov/coronavirus/2019-ncov/science/sciencebriefs/sars-cov-2-transmission.html. Accessed 26 Sept 2021

27. Katelaris AL, Wells J, Clark P, Norton S, Rockett R, Arnott A, et al. Epidemiologic evidence for airborne transmission of SARS-CoV-2 during church singing, Australia, 2020. Emerg Infect Dis. 2021;27:1677-80. https://doi. org/10.3201/eid2706.210465.

28. Wu Y, Guo C, Tang L, Hong Z, Zhou J, Dong X, et al. Prolonged presence of SARS-CoV-2 viral RNA in faecal samples. Lancet Gastroenterol Hepatol. 2020:5:434-5. https://doi.org/10.1016/S2468-1253(20)30083-2.

29. Wang W, Xu Y, Gao R, Lu R, Han K, Wu G, et al. Detection of SARS-CoV-2 in different types of clinical specimens. JAMA. 2020;323:1843-4. https://doi. org/10.1001/jama.2020.3786.

30. Xiao F, Sun J, Xu Y, Li F, Huang X, Li H, et al. Infectious SARS-CoV-2 in Feces of Patient with Severe COVID-19. Emerg Infect Dis. 2020;26:1920-2. https://doi.org/10.3201/eid2608.200681.

31. Zhou J, Li C, Liu X, Chiu MC, Zhao X, Wang D, et al. Infection of bat and human intestinal organoids by SARS-CoV-2. Nat Med. 2020;26:1077-83. https://doi.org/10.1038/s41591-020-0912-6.

32. Chen Y, Chen L, Deng Q, Zhang G, Wu K, Ni L, et al. The presence of SARSCoV-2 RNA in the feces of COVID-19 patients. J Med Virol. 2020;92:833-40. https://doi.org/10.1002/jmv.25825.

33. Xiao F, Tang M, Zheng X, Liu Y, Li X, Shan H. Evidence for gastrointestinal infection of SARS-CoV-2. Gastroenterology. 2020;158:1831-1833.e3. https://doi.org/10.1053/j.gastro.2020.02.055.

34. Slaats MALJ, Versteylen M, Gast KB, Oude Munnink BB, Pas SD, Bentvelsen RG, et al. Case report of a neonate with high viral SARSCoV-2 loads and long-term virus shedding. J Infect Public Health. 2020;13:1878-84. https://doi.org/10.1016/j.jiph.2020.10.013.
35. Xing Y-H, Ni W, Wu Q, Li W-J, Li G-J, Wang W-D, et al. Prolonged viral shedding in feces of pediatric patients with coronavirus disease 2019. J Microbiol Immunol Infect. 2020;53:473-80. https://doi.org/10.1016/j.jmii. 2020.03.021.

36. van Doorn AS, Meijer B, Frampton CMA, Barclay ML, de Boer NKH. Systematic review with meta-analysis: SARS-CoV-2 stool testing and the potential for faecal-oral transmission. Aliment Pharmacol Ther. 2020;52:1276-88. https://doi.org/10.1111/apt.16036.

37. Yuan $C$, Zhu H, Yang Y, Cai X, Xiang F, Wu H, et al. Viral loads in throat and anal swabs in children infected with SARS-CoV-2. Emerg Microbes Infect. 2020;9:1233-7. https://doi.org/10.1080/22221751.2020.1771219.

38. Hua C, Miao Z, Zheng J, Huang Q, Sun Q, Lu H, et al. Epidemiological features and viral shedding in children with SARS-CoV-2 infection. J Med Virol. 2020;92:2804-12. https://doi.org/10.1002/jmv.26180.

39. De loris MA, Scarselli A, Ciofi degli Atti ML, Ravà L, Smarrazzo A, Concato $C$, et al. Dynamic viral severe acute respiratory syndrome coronavirus 2 RNA shedding in children: preliminary data and clinical consideration from a Italian Regional Center. J Pediatric Infect Dis Soc. 2020;9:366-9. https://doi.org/10.1093/jpids/piaa065.

40. Cai J, Wang X, Zhao J, Ge Y, Xu J, Tian H, et al. Comparison of clinical and epidemiological characteristics of asymptomatic and symptomatic SARSCoV-2 infection in children. Virol Sin. 2020;35:803-10. https://doi.org/10. 1007/s12250-020-00312-4.

41. Han MS, Seong M-W, Heo EY, Park JH, Kim N, Shin S, et al. Sequential analysis of viral load in a neonate and her mother infected with severe acute respiratory syndrome coronavirus 2. Clin Infect Dis. 2020;71:2236-9. https://doi.org/10.1093/cid/ciaa447.

42. Olivini N, Calò Carducci Fl, Santilli V, De loris MA, Scarselli A, Alario D, et al. A neonatal cluster of novel coronavirus disease 2019: clinical management and considerations. Ital J Pediatr. 2020;46:180. https://doi.org/10. 1186/s13052-020-00947-9.

43. Zeng L, Xia S, Yuan W, Yan K, Xiao F, Shao J, et al. Neonatal early-onset infection with SARS-CoV-2 in 33 neonates born to mothers with COVID19 in Wuhan, China. JAMA Pediatr. 2020;174:722. https://doi.org/10.1001/ jamapediatrics.2020.0878.

44. Zhang Z-J, Yu X-J, Fu T, Liu Y, Jiang Y, Yang BX, et al. Novel coronavirus infection in newborn babies aged $<28$ days in China. Eur Respir J. 2020;55:2000697. https://doi.org/10.1183/13993003.00697-2020.

45. Wang S, Guo L, Chen L, Liu W, Cao Y, Zhang J, et al. A case report of neonatal 2019 coronavirus disease in China. Clin Infect Dis. 2020;71:853-7. https://doi.org/10.1093/cid/ciaa225.

46. Meslin P, Guiomard C, Chouakria M, Porcher J, Duquesne F, Tiprez C, et al. Coronavirus disease 2019 in newborns and very young infants. Pediatr Infect Dis J. 2020;39:e145-7. https://doi.org/10.1097/INF.0000000000002743.

47. Elahi S. Neonatal and children's immune system and COVID-19: biased immune tolerance versus resistance strategy. J Immunol. 2020;205:19907. https://doi.org/10.4049/jimmunol.2000710.

48. Hamming I, Timens W, Bulthuis M, Lely A, Navis G, van Goor H. Tissue distribution of ACE2 protein, the functional receptor for SARS coronavirus. A first step in understanding SARS pathogenesis. J Pathol. 2004;203:631-7. https://doi.org/10.1002/path.1570.

49. Zhang H, Li H-B, Lyu J-R, Lei X-M, Li W, Wu G, et al. Specific ACE2 expression in small intestinal enterocytes may cause gastrointestinal symptoms and injury after 2019-nCoV infection. Int J Infect Dis. 2020;96:19-24. https://doi.org/10.1016/j.jijid.2020.04.027.

\section{Publisher's Note}

Springer Nature remains neutral with regard to jurisdictional claims in published maps and institutional affiliations. 